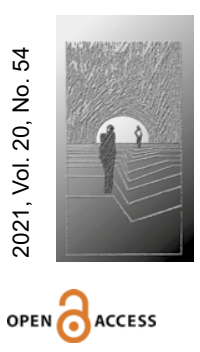

Elżbieta A. Maj

http://orcid.org/0000-0003-2458-5093 Uniwersytet Pedagogiczny w Krakowie elzbieta.maj@up.krakow.pl

Natalia Maj

http://orcid.org/0000-0002-8505-2402 Studentka logopedii w Instytucie Filologii Polskiej Uniwersytetu Pedagogicznego w Krakowie, członek Centrum Badań Prawnych nad Dzieckiem i Rodziną UP

majnatalia@interia.pl

DOI: 10.35765/hw.2050

\title{
Nauczanie online w kontekście postępu edukacyjnego i terapeutycznego dziecka ze specyficznymi trudnościami w uczeniu się
}

\section{STRESZCZENIE}

CEL NAUKOWY: Praca poddaje refleksji formy prowadzenia zajęć lekcyjnych po zmianie metodyki na nauczanie zdalne, jak również obrazuje możliwości postępu - zarówno edukacyjnego, jak i terapeutycznego - dzieci ze specyficznymi trudnościami w uczeniu się.

PROBLEM I METODY BADAWCZE: Wiodącym problemem badawczym jest pytanie o korelat „Covidowych" modeli funkcjonowania oświaty ze specyfiką objawową oraz terapeutyczną dysleksji. Biorąc pod uwagę interdyscyplinarność problemu leżącego na zbiegu pedagogiki i prawa, do badań pedagogicznych zastosowano metodę monograficzną, a do prawnych - metodę dogmatycznoprawną.

PROCES WYWODU: Publikację rozpoczyna opis zaburzenia dysleksji i jego skutków w sferze społecznej i oświatowej. Następnie analizie poddano prawne podstawy funkcjonowania placówek oświatowych w warunkach tradycyjnych oraz reżimu pandemicznego (SARS-CoV-2).

WYNIKI ANALIZY NAUKOWEJ: Z przeprowadzonych badań wynika, że okres pandemii, który wymusił system nauczania zdalnego, przekłada się na ograniczone możliwości terapeutyczne wobec uczniów z zaburzeniem dysleksji oraz niemal całkowicie wyeliminował możliwość wczesnej diagnozy nauczycielskiej.

WNIOSKI, INNOWACJE, REKOMENDACJE: Pandemia koronawirusa pozostawia niezaprzeczalny ślad na procesie edukacyjnym uczniów szkół podstawowych, zwłaszcza uczniów ze specyficznymi trudnościami w uczeniu się. Obszarem, który uległ zdecydowanemu zaniedbaniu ze względu na pozbawienie nauczycieli możliwości bezpośredniego kontaktu ze swoimi uczniami, jest obszar wczesnej diagnozy oraz profilaktyki występowania zaburzeń rozwojowych oraz trudności w uczeniu się.

$\rightarrow$ SŁOWA KLUCZOWE: OŚWIATA, DYDAKTYKA, DYSLEKSJA, PANDEMIA, KORONAWIRUS 


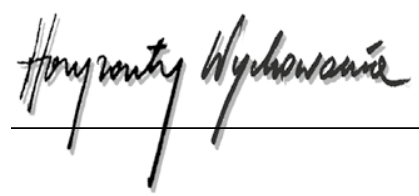

ABSTRACT

Online Teaching in the Context of Educational and Therapeutic Progress of a Child with Specific Learning Difficulties

RESEARCH OBJECTIVE: The work reflects on the forms of teaching after changing the methodology to remote learning, as well as illustrates the possibilities of progress - both educational and therapeutic - for children with specific learning difficulties.

THE RESEARCH PROBLEM AND METHODS: The leading research problem is the question about the correlation between "covid” models of the functioning of education and the symptomatic and therapeutic specificity of dyslexia. Taking into account the interdisciplinarity of the problem lying at the intersection of pedagogy and law, the monographic method used for pedagogical research, and the dogmatic-legal method was used for legal research.

THE PROCESS OF ARGUMENTATION: The publication begins with a description of dyslexia and its consequences in the social and educational sphere. Then, the legal basis for the functioning of educational institutions in traditional conditions and in the pandemic regime (SARS-CoV-2) was analyzed.

RESEARCH RESULTS: The conducted research shows that the pandemic period, which was forced by the distance learning system, transfers into limited therapeutic options for students with dyslexia and almost completely eliminated the possibility of early teacher diagnosis.

CONCLUSIONS, INNOVATIONS, AND RECOMMENDATIONS: The coronavirus pandemic leaves an undeniable mark on the educational process of primary school students, especially students with specific learning disabilities. An area that has been largely neglected due to the fact that teachers are deprived of direct contact with their students is the area of early diagnosis and prevention of developmental disorders and learning difficulties.

\section{$\rightarrow$ KEYWORDS: EDUCATION, DIDACTICS, DYSLEXIA, PANDEMIC, CORONAVIRUS}

\section{Wstęp}

Rok 2019, w którym rozpoczęła się pandemia koronawirusa, stał się początkiem wielu zmian dotykających znacznej części domen życia społecznego. Skutki obostrzeń w sposób pośredni lub bezpośredni dotknęły niemal wszystkich branż i środowisk. Znaczny wpływ tych koniecznych, lecz zubożających zmian zauważyć można także w działalności oświatowej, edukacyjnej, pedagogicznej czy terapeutycznej. Nowa rzeczywistość przepełniona ograniczeniami oraz nowymi metodami pracy nie tworzy niestety środowiska sprzyjającego postępowi edukacyjnemu i terapeutycznemu. Szczególną trudność w odnalezieniu się w nowo nakreślonej codzienności wykazują dzieci dotknięte różnymi zaburzeniami rozwojowymi. Świat, w którym zaczęły czuć się coraz swobodniej 
za sprawą programów terapeutycznych, zastąpiony został nowym, nieznanym wymiarem. Dodając do tego obniżenie poziomu edukacyjnego, brak bezpośredniego kontaktu z nauczycielem, nierzadko problemy natury technicznej oraz utrudnione lub wręcz uniemożliwione kontakty z grupą rówieśniczą, można łatwo dostrzec ogrom niedogodności, z jakimi musi zmierzyć się dziecko wykazujące obserwowalne trudności w funkcjonowaniu. Pandemia koronawirusa i wszystkie związane z nią obostrzenia mają więc bezpośredni wpływ na rozwój edukacyjny, społeczny i emocjonalny wszystkich dzieci, ale w szczególności tych zdiagnozowanych pod kątem zaburzenia dysleksji czy alalii.

Wiodącym problemem badawczym staje się zatem pytanie o korelat nowych, „covidowych" modeli funkcjonowania oświaty ze specyfiką objawową oraz terapeutyczną dysleksji. Na gruncie przyjętych uogólnień postawiona zostaje hipoteza zakładająca wymierność negatywnego wpływu zdalnych form edukacji nie tylko na psychikę dziecka, ale przede wszystkim na postęp terapeutyczny. Dzieci pozbawione bezpośredniej diagnostyki nauczycielskiej nie tylko mają mniejsze szanse na odpowiednio szybko zaordynowaną terapię, ale narażone są także na stagnację, a może i wręcz pogłębienie dysfunkcji edukacyjnych.

Biorąc pod uwagę interdyscyplinarność problemu leżącego na zbiegu pedagogiki i prawa, a tym samym kompleksowy charakter badań, metody dopasowano na zasadach dualnych. Do badań pedagogicznych zastosowano metodę monograficzną, analizę prawnych podstaw funkcjonowania systemu oświaty w dobie przed- i „pocovidowej” przeprowadzono natomiast na podstawie metody dogmatycznoprawnej.

\section{Funkcjonowanie dziecka dyslektycznego w otoczeniu szkolnym i społecznym}

W obiegu naukowym powszechnie stosowanych jest wiele definicji dysleksji. Według Jagody Cieszyńskiej-Rożek dysleksja „charakteryzuje się trudnościami w linearnym opracowywaniu informacji językowych, którym towarzyszą problemy w sekwencyjnym przetwarzaniu informacji symbolicznych, czasowych i motorycznych" (Cieszyńska, 2016, s. 332). Zaburzenia w linearnym przetwarzaniu informacji ściśle wiążą się z lewą półkulą mózgu, która odpowiada za liniowe oraz sekwencyjne uporządkowanie odbieranych bodźców. Osoba z zaburzeniem lewopółkulowego przetwarzania informacji będzie przejawiała problemy z aktywnościami dotykającymi właściwie każdej modalności (Cieszyńska-Rożek, 2013, s. 219). Trzeba bowiem pamiętać, że deficyt linearnego przetwarzania nie przenosi się jedynie na sprawności oceniane podczas lekcji języka polskiego. Ciągami liniowo uporządkowanych znaków symbolicznych są również cyfry czy nuty. Sekwencyjne uporządkowanie ruchów jest z kolei niezbędną umiejętnością pozwalającą na sprawne poruszanie się podczas zajęć wychowania fizycznego. Objawów dysleksji należy zatem szukać w działalności ucznia dotyczącej każdego przedmiotu nauczania. Co więcej, poszukiwania powinny wyjść poza granicę zajęć lekcyjnych - na korytarz szkolny, podwórko, boisko. Te obszary powinny podlegać szczególnej obserwacji 


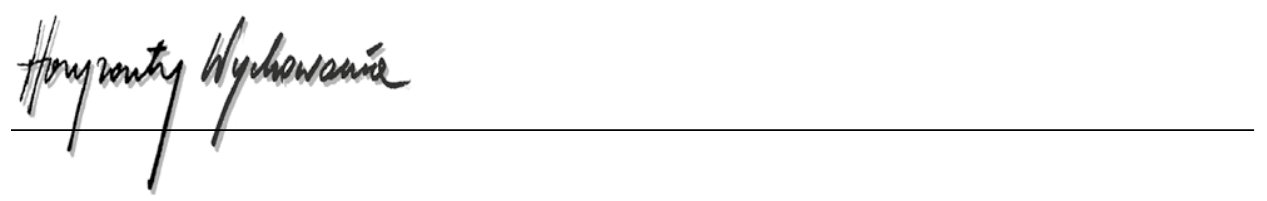

nauczyciela, ponieważ poza zauważalnymi objawami dysleksji dotyczącymi koordynacji ruchów, sposobów wypowiadania się czy rozumienia, są to miejsca, w których najłatwiej zaobserwować ewentualne symptomy wykluczenia dziecka z grupy rówieśniczej. Warto bowiem podkreślić, że dysleksja może skutkować problemami dziecka w sferze społecznej (Krasowicz-Kupis, 2009, s. 161), a szybkie zaobserwowanie oznak braku akceptacji w grupie pozwala na odpowiednią reakcję i udzielenie dziecku koniecznego wsparcia.

\section{Funkcjonowanie placówek edukacyjnych oraz poradni psychologiczno-pedagogicznych w kontakcie z uczniem dyslektycznym}

Zadania placówek oświatowych, w kontekście pracy z dzieckiem z dysleksją, są różne i ogólnie nakreślone przez ustawę z dnia 14 grudnia 2016 r. - Prawo oświatowe (t.j. Dz.U. z 2020 r., poz. 910 ze zm.). Rozporządzenie Ministra Edukacji Narodowej z dnia 9 sierpnia 2017 r. w sprawie zasad organizacji i udzielania pomocy psychologiczno-pedagogicznej w publicznych przedszkolach, szkołach i placówkach (t.j. Dz.U. z 2020 r., poz. 1280) zawiera natomiast uregulowania szczegółowe dotyczące pomocy dziecku z trudnościami edukacyjnymi z uwzględnieniem roli szkoły oraz poradni psychologiczno-pedagogicznej. Paragraf 2 ust. 1 rozporządzenia stanowi, że to przedszkole i szkoła/placówka odpowiadają za rozpoznanie obserwowalnych trudności edukacyjnych dziecka. W literaturze wyróżnia się zasady wykorzystywane w procesie uczenia się i rozwoju, w tym zasadę indywidualizacji (Placha, 2010, s. 26). Nauczyciele powinni zatem realizować indywidualne podejście do uczniów, umożliwiające wnikliwą obserwację rozwoju edukacyjnego oraz psychofizycznego wychowanka. Jest to niezwykle ważne, ponieważ jedynie bezpośredni kontakt z dzieckiem może skutkować wychwyceniem zaburzeń w którejkolwiek ze sfer rozwoju, a tym samym szybką interwencję mającą na celu postawienie diagnozy i wdrożenie terapii na jak najwcześniejszym etapie rozwoju zaburzenia. Trzeba pamiętać, że im później zdiagnozowane zaburzenie, tym więcej czasu dostaje dziecko na nabycie i zautomatyzowanie nieprawidłowych strategii radzenia sobie z zadaniami (Korendo, b.d., s. 2). W zasadzie od momentu zaobserwowania występujących u ucznia trudności rozpoczyna się współpraca pomiędzy szkołą a poradnią, mająca na celu usprawnienie funkcjonowania dziecka w sferze edukacyjnej, jak również społecznej i emocjonalnej.

Rozporządzenie z 2017 r. określa zakres współpracy szkół z innymi podmiotami, wskazując m.in. na rodziców, wspomniane poradnie psychologiczno-pedagogiczne oraz poradnie specjalistyczne, placówki edukacyjne oraz organizacje pozarządowe działające na rzecz rodziny, dzieci i młodzieży (§ 4 ust. 3). Podejmowane działania powinny skupiać się na wdrożeniu różnego rodzaju zajęć kompensacyjnych czy rozwijających, jak również na zindywidualizowaniu ścieżki kształcenia (§ 6 ust. 1, 2, 3, 4). Paragraf 20 ust. 1 rozporządzenia określa szczegółowo zadania nauczycieli, wychowawców oraz specjalistów w placówkach oświatowych, kładąc nacisk na rozpoznawanie indywidualnych potrzeb edukacyjnych i rozwojowych oraz możliwości psychofizycznych uczniów, 
a także rozpoznawanie przyczyn ich niepowodzeń edukacyjnych. Oznacza to, że zadaniem nauczyciela jest nie tylko ocena funkcjonowania ucznia w sferze edukacyjnej, ale również społeczno-środowiskowej. Jak bowiem podkreślono, trudności edukacyjne mają bezpośredni wpływ na odbiór społeczny dziecka, co wtórnie może przerodzić się w brak akceptacji środowiska rówieśniczego, a więc w czynnik stanowiący istotne zagrożenie dla jego prawidłowego emocjonalnego i społecznego rozwoju.

W literaturze wyróżnia się trzy podstawowe typy statusów dziecka w grupie rówieśniczej: dzieci popularne, dzieci nieakceptowane oraz dzieci ignorowane (Kołodziejczyk, 2011 , s. 246). Dzieci ignorowane wykazują skłonności do unikania kontaktów rówieśniczych - nietrudno o zauważanie tutaj analogii z dziećmi alalicznymi, które często, pomimo początkowo wysokiej intencji komunikacyjnej, wskutek kolejnych porażek komunikacyjnych rezygnują z nawiązywania kontaktów, wolą bawić się same lub z dziećmi młodszymi, które nie zwrócą uwagi na ich ograniczenia werbalne. Stanowi to kolejny niezaprzeczalny dowód na konieczność wnikliwej obserwacji ucznia w środowisku, w przedszkolu lub szkole i na konieczność szybkiej interwencji w momencie zaobserwowania jakichkolwiek trudności w sferze edukacyjnej, społecznej czy emocjonalnej. Interwencja w środowisku ucznia to jedna z form pomocy uczniowi polegająca na poznaniu dziecka oraz jego trudności w warunkach dla niego naturalnych (Skałbania, 2009, s. 74). Tylko podjęcie rzetelnej współpracy szkoły z poradnią psychologiczno-pedagogiczną lub specjalistyczną oraz z rodzicami może skutkować sprawnym zdiagnozowaniem oraz rozpoczęciem terapii zaburzenia. Taki model postępowania znacząco ogranicza czynniki mające wpływ na kształtowanie się negatywnego obrazu samego siebie, a postępy i sukcesy edukacyjne, będące wynikiem terapii, mogą mieć pozytywny wpływ na samoocenę ucznia oraz jego kontakty z grupą. Na gruncie badań nad cechami osobowości uczniów szkół średnich i studentów z dysleksją rozwojową, prowadzonych przez Bożenę Wszeborowską-Lipińską, wypracowano zestaw cech osobowości osoby z dysleksją. Wśród nich znajduje się cecha świadcząca o zwiększeniu pewności siebie w momencie osiągnięcia sukcesu w nauce (Krasowicz-Kupis, 2009, s. 169). Odkrycie to potwierdza ścisłą korelację pomiędzy sferą edukacyjną a społeczno-emocjonalną człowieka i tym samym wyznacza kierunek działalności nauczyciela w kontekście profilaktyki zaburzeń w każdej ze sfer.

\section{Zmiany w działalności jednostek systemu oświaty w związku z zapobieganiem, przeciwdziałaniem i zwalczaniem COVID-19}

Od 4 marca 2020 r., a więc od momentu zdiagnozowania pierwszego pacjenta zakażonego koronawirusem SARS-CoV-2, każdy obszar działalności człowieka w większym lub mniejszym stopniu zaczął podlegać nieustannym zmianom, będącym wynikiem sytuacji epidemicznej w kraju i na świecie. Zmiany te nie ominęły również organizacji pracy szkół i innych placówek oświatowych, w tym poradni psychologiczno-pedagogicznych. Zdaniem Marty Bogdanowicz - cytowanej przez Ewę A. Zwolińską - „system pomocy 


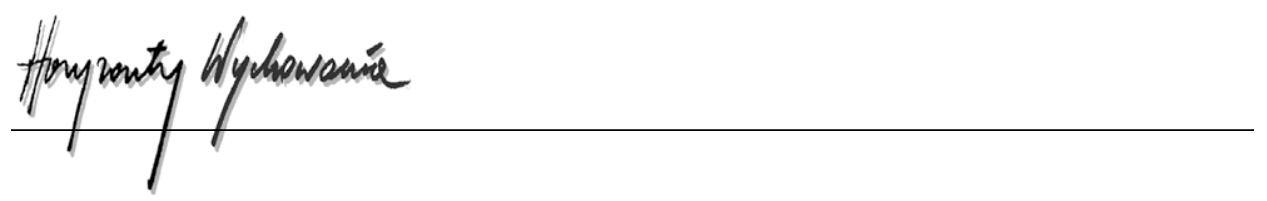

terapeutycznej w Polsce jest trafny i spójny, ale nie funkcjonuje skutecznie z powodu braku dostępności do różnorodnych form pomocy" (Zwolińska, 2010, s. 47). Wynika z tego, że system nie był w pełni wydolny w trakcie normalnej organizacji pracy, a co dopiero w trybie kryzysowym. W imię przywołanych warunków kryzysowych na przestrzeni ostatnich miesięcy kilkukrotnie modyfikowano model prowadzenia zajęć lekcyjnych, wprowadzano ograniczenia w działalności państwowych poradni psychologiczno-pedagogicznych oraz poradni specjalistycznych. Dodatkowo obostrzeniom i reżimowi sanitarnemu musiały podporządkować się wszystkie prywatne placówki, poradnie czy gabinety. W niniejszej publikacji zostaną pominięte regulacje modyfikujące działalność jednostek systemu oświaty, które utraciły już status aktów obowiązujących. Analizie poddane zostaną przepisy aktualne na dzień 20 marca 2021 r., stanowiące regulator działania szkół oraz poradni w kontekście pracy z dziećmi ze specyficznymi trudnościami w uczeniu się.

Mocą rozporządzenia Ministra Edukacji Narodowej z dnia 12 sierpnia 2020 r. w sprawie czasowego ograniczenia funkcjonowania jednostek systemu oświaty w związku z zapobieganiem, przeciwdziałaniem i zwalczaniem COVID-19 (Dz.U. poz. 1389) wraz ze zmianami wprowadzonymi rozporządzeniami z dnia: 16 października 2020 r. (Dz.U. poz. 1830), 23 października 2020 r. (Dz.U. poz. 1870), 5 listopada 2020 r. (Dz.U. poz. 1960), 24 listopada 2020 r. (Dz.U. poz. 2087), 13 stycznia 2021 r. (Dz.U. poz. 92), 28 stycznia 2021 (Dz.U. poz. 202), 12 lutego 2021 r. (Dz.U. poz. 283), 26 lutego 2021 r. (Dz.U. poz. 366), 11 marca 2021 r. (Dz.U. poz. 448) i 18 marca 2021 r. (Dz.U. poz. 502) znaczącym zmianom uległ model funkcjonowania szkół podstawowych, szkół ponadpodstawowych, placówek kształcenia ustawicznego i centrów kształcenia zawodowego, ośrodków rewalidacyjno-wychowawczych oraz szkolnych schronisk młodzieżowych.

Wśród przywołanych nowelizacji rozporządzenie z dnia 13 stycznia 2021 r. wyszczególniło przypadki, w których realizowanie zajęć w formie konwencjonalnej oddano do decyzji dyrektora placówki. Regulacje te dotyczyły jednak tylko szkół podstawowych specjalnych w zakresie klas IV-VIII oraz szkół ponadpodstawowych specjalnych, szkół podstawowych specjalnych w zakresie klas IV-VIII oraz szkół ponadpodstawowych specjalnych, funkcjonujących w specjalnych ośrodkach szkolno-wychowawczych oraz w podmiotach leczniczych i jednostkach pomocy społecznej. Z kolei rozporządzenie z dnia 28 stycznia 2021 r. upoważniło dyrektorów placówek do zorganizowania uczniom zajęć w szkole lub umożliwienia im realizacji zajęć z wykorzystaniem metod i technik kształcenia na odległość na terenie szkoły. Upoważnienie to dotyczyło jednak tylko uczniów szkół podstawowych w zakresie klas IV-VIII oraz szkół ponadpodstawowych, którzy z uwagi na rodzaj niepełnosprawności nie mogli realizować zajęć z wykorzystaniem metod i technik kształcenia na odległość. Warto zatem podkreślić, że dzieci wykazujące specyficzne trudności w uczeniu się nie zostały objęte przywilejem uczestnictwa w zajęciach prowadzonych w szkole, co w kontekście omawianych wyżej problemów wiąże się ze znaczącym utrudnieniem realizacji przez nich podstawy programowej.

Czas pandemii stał się zatem czasem rozłamu edukacyjnego wynikającego z konieczności nagłej zmiany metodyki nauczania. Ze szkół, w których bezpośrednie i indywidualne podejście do ucznia stanowiło podstawę pracy, proces nauczania przeniósł się 
do przestrzeni cyfrowej. W tych nieoczekiwanych warunkach początkowo wielu nauczycieli nie potrafiło się odnaleźć, co w dużej mierze zaważyło na indywidualizacji procesu dydaktycznego. Warto zwrócić także uwagę na fakt, że w wielu szkołach drugi semestr roku szkolnego 2019/2020 przebiegał w nienaturalnych dla standardów pedagogicznych warunkach, w których niewykwalifikowany pod względem metodycznym, psychologiczno-pedagogicznym oraz dydaktycznym rodzic przejmował dominującą rolę w procesie kształcenia dziecka.

Badania oparte na doświadczeniach ostatniego roku podkreślają nie tylko wagę doboru odpowiednich form nauczania cyfrowego - mulimedialnego, interaktywnego, synchronicznej komunikacji (Plebańska, 2020, s. 39), ale i korelatu możliwości technicznych zarówno po stronie nauczyciela, jak i ucznia, zasobów edukacyjnych oraz kompetencji kadry dydaktycznej (Koludo, 2020, s. 43). Przyczyn trudnych początków zdalnego nauczania w 2020 r. upatrywać można zatem w deficytach sprzętowych nauczycieli, ograniczonej biegłości technologicznej, a być może także w braku rozwoju zawodowego nauczycieli, na co zwraca uwagę Joanna Łukasik (2018, s. 29).

Jak podkreśla Marlena Plebańska, pomimo wielu pozytywnych cech edukacji cyfrowej używanie jej jako wiodącej lub jedynej formy nauczania wydaje się trudne do realizacji na wszystkich poziomach kształcenia (Plebańska, 2020, s. 380). Na pewno brak komunikacji bezpośredniej na linii nauczyciel-uczeń ma zasadniczy wpływ na kształtowanie postępów w nauce dzieci ze specjalnymi potrzebami edukacyjnymi. Uczeń z trudnościami w uczeniu się, w tym z dysleksją, popełnia mnóstwo błędów, które niekorygowane mogą się utrwalić oraz rozprzestrzenić. Podczas nauki stacjonarnej zeszyty uczniów podlegają regularnej rewizji pod kątem błędów merytorycznych oraz formalnych. Niestety era nauczania na odległość wpłynęła na ograniczenie nauczycielskiego feedbacku do oceny sprawdzianów oraz okazjonalnych zadań wymagających przesłania zdjęcia z odpowiedzią pisemną.

\section{Zakończenie}

Nadejście pandemii koronawirusa odcisnęło niezaprzeczalny ślad na procesie edukacyjnym uczniów, szczególnie tych ze specjalnymi potrzebami edukacyjnymi.

Badania „Zdalne nauczanie a adaptacja do warunków społecznych w czasie epidemii koronawirusa" przeprowadzone w 2020 r. ten stan zdecydowanie potwierdzają. Przedmiotowym badaniem objęto blisko tysiąc rodziców lub opiekunów, z czego $20 \%$ stanowili opiekunowie uczniów o specjalnych potrzebach edukacyjnych, posiadających orzeczenie o niepełnosprawności lub opinię z poradni psychologiczno-pedagogicznej. Wyniki szczegółowe pokazują, że blisko 40\% nauczycieli w trakcie edukacji zdalnej nie dyktowało uczniom notatek podczas lekcji (przed pandemią zaledwie 17\%). Uczniowie dyslektyczni, mający trudności w samodzielnym robieniu notatek, zostali tym samym pozbawieni materiałów do nauki. Wskazują na to dalsze analizy, według których ponad jedna czwarta uczniów (27\%) miała problem ze skoncentrowaniem się na lekcji i prawie 


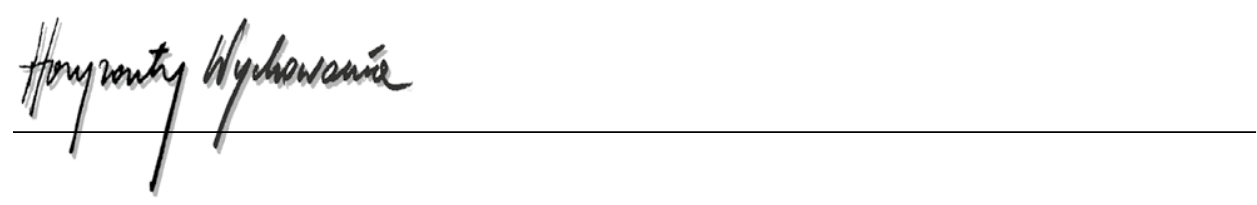

tyle samo miało trudności z rozumieniem przekazywanej wiedzy (26\%). Niemal co piąty uczeń (19\%) nie potrafił na lekcji czasowo wykonywać zleconych zadań (Ptaszek i in., 2020 , s. $20,26,27)$.

Obszarem, który uległ ogromnemu osłabieniu ze względu na pozbawienie nauczycieli możliwości bezpośredniego kontaktu ze swoimi uczniami, jest także obszar wczesnej diagnozy oraz profilaktyki występowania zaburzeń rozwojowych oraz trudności w uczeniu się. Wiele ograniczeń nałożonych na szkoły oraz poradnie psychologiczno-pedagogiczne utrudniło współpracę pomiędzy specjalistami, która - jak należy podkreślić - jest nieodzowna w procesie diagnostycznym i terapeutycznym.

W przypadku dzieci wcześniej zdiagnozowanych obserwowalne są niepokojące sygnały wynikające m.in. z braku stałej kontroli postępów oraz nieobecności konstruktywnego feedbacku. Pomimo że obraz tych zmian jest możliwy do zaobserwowania już teraz, pokłosie pandemicznych transformacji będzie wymagało obszernych badań w niedalekiej przyszłości.

Pamiętać także należy, że utrudnienia, z jakimi zmaga się dziecko z dysleksją w dobie nauczania online, mają bezpośredni wpływ nie tylko na proces zdobywania wiedzy czy umiejętności, ale i jego psychikę. Negatywny obraz samego siebie wynikający z piętrzących się niepowodzeń szkolnych może prowadzić do wielu zaburzeń o podłożu psychicznym, w tym do poczucia lęku i osamotnienia oraz stanów depresyjnych (Półtorak, 2017, s. 72).

W obliczu pojawiających się trudności poznawczych wśród uczniów nie wystarcza zatem tylko kreatywny dobór ciekawych form nauczania, jak: czat, gry sieciowe, wideokonferencje, współredagowalne dokumenty, projekty, prezentacje, quizy, biblioteki cyfrowe, audioteki i inne (Walter, 2020, s. 57), ale każdorazowo dokonywać należy ich indywidualizacji z punktu widzenia grupy, a nawet poszczególnych uczniów.

Za konkluzje niech posłużą słowa Piotra Plichty na temat uczniów wymagających specjalnej realizacji potrzeb edukacyjnych: „(...) nie ich potrzeby są specjalne, tylko oni wymagają szczególnego namysłu nauczyciela, znalezienia odpowiedniej drogi ich realizacji” (Plichta, 2020, s. 71).

\section{BIBLIOGRAFIA}

Cieszyńska, J. (2016). Zaburzenia linearności - podstawowy wymiar trudności w czytaniu i pisaniu. W: S. Milewski i K. Kaczorowska-Bray (red.), Logopedia. Wybrane aspekty historii, teorii i praktyki (s. 322-328). Gdańsk: Wydawnictwo Harmonia.

Cieszyńska-Rożek, J. (2013). Metoda Krakowska wobec zaburzeń rozwoju dzieci. Z perspektywy fenomenologii, neurobiologii i językoznawstwa. Kraków: Wydawnictwo Centrum Metody Krakowskiej.

Koludo, A. (2020) Strategie kształcenia na odległość. W: J. Pyżalski (red.), Edukacja w czasach pandemii wirusa COVID-19. Z dystansem o tym, co robimy obecnie jako nauczyciele (s. 4350). Warszawa: EduAkcja.

Kołodziejczyk, A. (2011). Późne dzieciństwo - młodszy wiek szkolny. W: J. Trempała (red.), Psychologia rozwoju człowieka (s. 235-258). Warszawa: Wydawnictwo Naukowe PWN. 
Korendo, M. (b.d.). Dysleksja - problem cywilizacyjny. https://centrummetodykrakowskiej.pl/media/ upload/site/0/20/file/ce82e190be244e5f80bb7532946f580b_Dysleksja\%20-\%20problem\%20 cywilizacyjny

Krasowicz-Kupis, G. (2009). Psychologia dysleksji. Warszawa: Wydawnictwo Naukowe PWN.

Łukasik, J.M. (2018). Rozwój osobisty nauczyciela - nieobecna kategoria. Ruch Pedagogiczny, 2, 29-37.

Placha, J. (2010). Optymalizacja procesu uczenia się i rozwoju. W: W. Brejnak i W. Woźniak (red.), Pomoc psychologiczno-pedagogiczna. Wybrane zagadnienia (s. 26). Łódź: Wydawnictwo Wyższej Szkoły Edukacji Zdrowotnej i Nauk Społecznych.

Plebańska, M. (2020), Cyfrowa edukacja - potencjał, procesy, modele. W: J. Pyżalski (red.), Edukacja w czasach pandemii wirusa COVID-19. Z dystansem o tym, co robimy obecnie jako nauczyciele (s. 37-42). Warszawa: EduAkcja.

Plichta, P. (2020). Różne konteksty nierówności cyfrowych a wyzwania dla zdalnej edukacji - propozycje rozwiązań. W: J. Pyżalski (red.), Edukacja w czasach pandemii wirusa COVID-19. $Z$ dystansem o tym, co robimy obecnie jako nauczyciele (s. 70-80). Warszawa: EduAkcja.

Półtorak, M. (2017). Psychospołeczne funkcjonowanie dzieci z dysleksją rozwojową - wybrane aspekty. W: A. Myszka, K.I. Bieńkowska i I. Marczykowska (red.), Głos - Język-Komunikacja. T. 4: Funkcjonowanie społeczne dzieci z problemami komunikacyjnymi (s. 69-78). Rzeszów: Wydawnictwo Uniwersytetu Rzeszowskiego.

Ptaszek, G., Stunża, G.D., Pyżalski, J., Dębski, M. i Bigaj, M. (2020). Edukacja zdalna: co stało się z uczniami, ich rodzicami i nauczycielami? Gdańsk: Gdańskie Wydawnictwo Psychologiczne.

Skałbania, B. (2009). Poradnictwo pedagogiczne. Przegląd wybranych zagadnień. Kraków: Oficyna Wydawnicza "Impuls".

Walter, N. (2020). Mamy (za) duży wybór - jak nie zgubić się wśród narzędzi cyfrowych? W: J. Pyżalski (red.), Edukacja w czasach pandemii wirusa COVID-19. Z dystansem o tym, co robimy obecnie jako nauczyciele (s. 51-58). Warszawa: EduAkcja.

Zwolińska, E. (2010). Efektywność dydaktyczna zajęć korekcyjno-wychowawczych. Bydgoszcz: Wydawnictwo Uniwersytetu Kazimierza Wielkiego.

\section{Copyright and License}

This article is published under the terms of the Creative Commons Attribution - NoDerivs (CC BY- ND 4.0) License http://creativecommons.org/licenses/by-nd/4.0/ 